\title{
Міжнародная навуковая канферэнцыя „Беларусь і суседзі: шляхі фарміравання дзяржаўнасці, міжнацыянальныя і міждзяржаўныя адносіны"
}

$\mathrm{M}$ іжнародная навуковая канферэнцыя „Беларусь і суседзі: шляхі фарміравання дзяржаўнасці, міжнацыянальныя і міждзяржаўныя адносіны" стала ўжо традыцыйнай на гістарычным факультэце Гомельскага дзяржаўнага ўніверсітэта імя Францыска Скарыны. 24-25 красавіка 2014 г. адбылася ўжо пятая канферэнцыя пад гэтай назвай. Праблемы ўзаемадзеяння народаў i дзяржаў Цэнтральнай і Усходняй Еўропы традыцыйна выклікаюць вялікую цікавасць з боку гісторыкаў розных краін. Гэта яскрава бачна, калі мы звернемся да прадстаўніцтва на канферэнцыі. Удзел у ёй узялі навукоўцы Беларусі, Польшчы, Украіны, Літвы, Славакіі. Праграма канферэнцыі ууключала каля ста дакладаў. У іх былі ўзняты актуальныя і важныя гістарычныя праблемы, звязаныя 3 фарміраваннем дзяржаўнасці, развіццём міжнародных адносін, культурных узаемасувязей паміж народамі і краінамі ўказанага вышэй рэгіёна.

Даклады, якія прагучалі на канферэнцыі, храналагічна ахоплівалі велізарны гістарычны перыяд: ад 14-15 стст. літаральна да нашых дзён. Шэраг даследчыкаў звярнуліся ў сваіх дакладах да эпохі Рэчы Паспалітай. Шматлікія аспекты эканамічнага, культурнага, канфесійнага жыцця беларускіх зямель ва ўмовах „дзяржавы двух народаў” былі раскрыты ў дакладах Ю. М. Бохана, I. Ф. Кітурака. Пытанні ваеннай гісторыі ВКЛ разгледжаны C. А. Чаропка. Наяўнасць прадстаўнічай групы ўкраінскіх гісторыкаў 
дазволіла разгледзець на канферэнцыі і шэраг праблем гісторыі Украіны ў складзе Рэчы Паспалітай, а затым і Расійскай імперыі. У прыватнасці, М.А. Федарэнка, В. А. Бакавецкая звярнуліся да рэлігійнай гісторыі ўкраінскіх зямель у 18-19 стст., А. В. Бабіна даў характарыстыку палітычнага руху на Украіне на мяжы 19 і 20 стст. Беларускія даследчыкі ў сваю чаргу паказалі спецыфіку сацыяльна-эканамічнага i духоўнага жыцця Беларусі ў складзе Расійскай імперыі. Так, С. Б. Жыхараў спыніўся на асаблівасцях расійскай дзяржаўнай палітыкі ў сферы чыгуначнага будаўніцтва.

Даклады, якія храналагічна адносяцца да 20 ст., былі пераважна прысвечаны двум асноўным праблемам: фарміраванню нацынальнай дзяржаўнасці і этнакультурным працэсам на тэрыторыі Цэнтральнай i Усходняй Еўропы ў першай палове 20 ст. і лёсам народаў і дзяржаў рэгіёна ва ўмовах ваенных катастроф 20 ст. Па першай праблеме гісторыкі з Беларусі, Украіны і Польшчы прааналізавалі працэсы фарміравання нацыянальнай свядомасці народаў Цэнтральнай i Усходняй Еўропы, развіцця нацыянальна-вызваленчага руху на беларускіх, украінскіх і польскіх землях. У работах М. Б. Шчаўлінскага, С. В. Чувак разгледжана праблема развіцця нацыянальнай свядомасці беларусаў. Шмат увагі ўдзельнікі канферэнцы надалі праблеме ўзаемадносін беларусаў 3 суседнімі народамі. М. I. Старавойтаў у сваім дакладзе ажыццявіў параўнальны аналіз этнадэмаграфічных змен у суседніх абласцях БССР, УССР і РСФСР у 1920-1930 гг. Праблема ўспрыняцця беларусамі і чырвонаармейцамі палякаў у час вайны 1920 г. і восенні 1939 г. раскрыта ў дакладах адпаведна А. М. Кротава і Д. М. Талочкі. Вялікі блок дакладаў быў прысвечаны гісторыі Заходняй Беларусі уу складзе Польшчы ў 19211939 гг. Характэрныя рысы сацыяльна-эканамічнага развіцця заходнебеларускіх зямель вызначаны ў выступленнях К. С. Разуванавай i Л. В. Лаўрэенка. Вялікую цікавасць у ўдзельнікаў канферэнцыі выклікалі пытанні гісторы нацыянальных меншасцей на тэрыторыі Беларусі. Так, прафесар Э. Р. Іофе разгледзеў становішча яўрэеў Беларусі ў гады Першай сусветнай вайны, a В. П. Пічукоў прадставіў унікальны матэрыял аб асірыйскай дыяспары на тэрыторыі Гомельшчыны. Шераг навукоўцаў, у прыватнасці, А. Д. Лебедзеў, І. І. Янушэвіч звярнуліся да гісторыі рэлігійнага жыцця.

Гісторыя міжнародных адносін у Цэнтральнай і Усходняй Еўропе, перш за ўсё ў гады паміж Першай і Другой сусветнымі войнамі, была цэнтральнай у праблемным полі канферэнцыі. Першыя даклады па гэтай тэматыцы прагучалі на пленарным пасяджэнні канферэнцыі. 
Прафесар Р. Р. Лазько ахарактарызаваў асновныя напрамкі палітыкі Савецкай Расіі ў дачыненні да Беларусі і Украіны ў першыя гады савецкай улады. Прафесар з Польшчы В. Матэрскі паказаў ролю Камінтэрна ў польска-савецкіх адносінах у 1923 г., а буйны беларускі спецыяліст у сферы гісторыі міжнародных адносін У. Е. Снапкоўскі даў агульную перыядызацыю польска-савецкіх адносін у 1944-1991 гг. Украінскі даследчык В. А. Тучынскі спыніўся на ўзаемадносінах украінскага і малдаўскага народаў.

Па праблематыцы Першай сусветнай вайны значнай навуковай навізной вызначаўся даклад А. М. Бабкова, прысвечаны рээвакуацыі бежанцаў і ваеннапалонных. С. В. Багалейша прааналізавала праекты стварэння беларуска-літоўскай дзяржавы ў час Першай сусветнай вайны. Спецыяліст з Літвы А. П. Касперавічус у сваім дакладзе выявіў перадумовы ўзнікнення і існавання Літоўскай рэспублікі ў міжваенны час. Д. А. Мігун вызначыў месца Беларусі ў савецка-германскіх адносінах перыяда Рапала. Для міжнароднапалітычнай сітуацыі ва Усходняй Еўропе вялікае значэнне меў Рыжскі дагавор. Дадзеная праблема рагледжана, у прыватнасці, у дакладзе В. Л. Кавунніка.

Розныя аспекты гісторыі Другой сусветнай вайны таксама знайшлі шырокае адлюстраванне ў дакладах, заслуханых на канферэнцыі. Пачатковы этап ваенных дзеянняў на тэрыторыі Беларусі летам 1941 г. на аснове арыгінальных матэрыялаў расійскіх архіваў асветлены ў дакладзе расійскага гісторыка В. В. Фядзюніна. Даследчык з Украіны Ф. I. Кокошко, працягваючы тэму ваенных дзеянняў на пачатковым этапе Вялікай Айчыннай вайны, зрабіў іх параўнальны аналіз на тэрыторыі Беларусі i Украіны. Яго польскі калега прафесар Я. Мірановіч вызначыў ролю і месца Беларусі ў нямецкай і савецкай палітыцы ў 1941-1944 гадах. Тэму нямецкай акупацыйнай палітыкі працягвала Л. У. Гаўрылавец, якая вызначыла яе асаблівасці на былых „усходніх крэсах” Другой Рэчы Паспалітай. У дакладзе С. Я. Новікава раскрыты шэраг аспектаў трагедыі савецкіх ваеннапалонных на тэрыторыі Беларусі.

У цэлым даклады, якія прагучалі на канферэнцыі вызначаліся высокай навуковай навізной і былі прысвечаны важным і актуальным праблемам гісторыі. Прадстаўнікі гістарычнай навукі з розных краін мелі магчымасць абмяняцца думкамі па разнастайных пытаннях гісторыі дзяржаў і народаў Цэнтральнай і Усходняй Еўропы, што спрыяла ўзаемнаму ўзбагачэнню начыянальных гістарыяграфій. 